\title{
Osteogenic Protein-1 Is Produced by Human Fetal Trophoblasts In Vivo and Regulates the Synthesis of Chorionic Gonadotropin and Progesterone by Trophoblasts In Vitro
}

\author{
Snježana Martinović ${ }^{1}$,Višnja Latin ${ }^{2}$, Ernest Suchanek ${ }^{2}$,Ana Stavljenić-Rukavina ${ }^{3}$, Kuber T. Sampath ${ }^{4}$ \\ and Slobodan Vukičević ${ }^{1}$ \\ 1 Department of Anatomy \\ 2 Department of Gynecology \\ 3 Department of Biochemistry \\ Medical School, Zagreb, Croatia \\ ${ }^{4}$ Creative BioMolecules, Hopkinton, MA, USA
}

Summary: Osteogenic protein-1 (OP-1/BMP-7), a member of the transforming growth factor (TGF- $\beta$ ) superfamily of proteins, is shown to be expressed at sites of epithelial-mesenchymal tissue interaction during human fetal development. In the present study, we examined the expression of OP-1 in human placentas (5-11 weeks of gestation and full term) using in situ hybridization and immunohistochemistry methods. The results show that OP1 was expressed in cytotrophoblasts (Langhans' layer) of the chorionic villi in early and full term placentas. Employing highly purified cytotrophoblast cultures which fused to form functional syncytiotrophoblasts, we showed that exogenously added recombinant OP-1, in the presence of low serum concentration, reduced the secretion of chorionic gonadotropin and progesterone by $60 \%$ and $36 \%$, respectively, compared with control cultures. The results suggest that osteogenic protein-1 is synthesized locally by cytotrophoblasts and may be involved in the regulation of human pregnancy by controlling reproductive hormonal secretion.

\section{Introduction}

Transforming growth factor-beta (TGF- $\beta$ ) is a superfamily of signalling proteins expressed temporally and spatially at specific sites of morphogenetic events during development. These proteins have been identified in various developmental systems, in both invertebrates and vertebrates. They include the activins and inhibins, osteogenic bone morphogenetic proteins OP-1 to OP-3 (2, $3)$ BMP-2 to BMP-6 $(4,5)$, mesoderm inducing factor from Xenopus laevis egg (Vg-1) (6), Muellerian inhibiting substance (MIS) (7), mammalian protein related to Xenopus Vg-1 (BMP-6) (8), growth/differentiation factors (GDF-1, GDF-3, GDF-9) $(9,10)$ and cartilage derived morphogenetic proteins (CDMP-1 and CDMP2 or GDF-5 and 6) $(11,12)$. The decapentaplegic (DPP) and $60 \mathrm{~A}$ proteins, which are involved in Drosophila pattern formations, are homologues of bone morphogenetic proteins $(13,14)$.

The proteins of the TGF- $\beta$ superfamily are produced as a precursor that is three times larger than mature protein; the precursor is then processed at proteolytic cleavage sites conforming to the sequence RXXR (3). The C-terminal mature proteins are composed of disulphidelinked dimers with striking identity in the conserved seven cysteine motifs (15). Despite the similar structural features, the temporal and spatial expression of these proteins suggest a functional specificity among them $(16-20)$. Osteogenic protein-1 (OP-1/BMP-7) induces new bone formation in vivo and plays a significant role in cartilage and bone metabolism (21-26).

The presence of high levels of osteogenic protein-1 message in the kidney $(19,27)$ suggests that OP-1 may have a role in the development of kidney. In addition, the presence of OP-1 in the uterus (28) and a steep decline of OP-1 expression at the onset of pregnancy suggest that reproductive hormones may influence and regulate osteogenic protein-1 expression locally in uterus (28).

In the present study, we examined the distribution of osteogenic protein-1 in human placentas during pregnancy, and examined the effect of OP-1 on the regulation of hormones associated with pregnancy using human trophoblast cultures. The results show that osteogenic protein-1 is expressed and plays a role in regulation of the hormonal secretion during pregnancy.

\section{Materials and Methods}

Human tissues

Whole human embryos (gestational age 5-14 weeks) obtained from legal abortions at the University of Zagreb Micdical School 
werc used in this study. The gestational age of each fetus was estimated on the basis of crown-rump length and pregnancy records of the conceptual age. The material was fixed at $4^{\circ} \mathrm{C}$ in paraformaldehyde $(40 \mathrm{~g} / \mathrm{l})$ in $0.1 \mathrm{~mol} / \mathrm{l}$ phosphate buffer $(\mathrm{pH}$ 7.2 ), embedded in paraffin and cut serially at $5 \mu \mathrm{m}$. The procedure for the human autopsy material was approved and controlled by the Internal Review Board of the Ethical Committee at the School of Medicine, the University of Zagreb, and the Office of Human Subjects Research (OHSR) at the National Institutes of Health, Bethesda, MD. The same collection has already been used for localizing bone morphogenetic protein-3 (BMP-3) and OP-1 in skeleton and abdominal organs during human development $(17-19)$.

\section{Mouse tissue}

Postimplantation embryos were obtained from outbred females mated with Fl males. At midday the vaginal plug was considered to be 0.5 days p.c. Tissues were fixed at $4{ }^{\circ} \mathrm{C}$ in $4 \%$ paraformaldehyde in phosphate-buffered saline, and embedded in paraffin. Serial sections were mounted on silanated glass slides, incubated overnight at $40-45^{\circ} \mathrm{C}$, and stored at $4{ }^{\circ} \mathrm{C}$ until use.

\section{Probe construction}

For the detection of mouse OP-1, a 679 base pair BstXI-BglI-fragment (pO 319-3) covering amino acids 63-263 of the pro-region and the first 25 amino acids of the N-terminal part of the mature polypeptide was used (27). The long fragment was subcloned into a pBluescript II (SK) ${ }^{+}$-vector, from which the Kpnl-Cla and SpelSacl multiple cloning site (MCS) fragments were eliminated to prevent cross-hybridization with ribosomal RNA sequences. Based on the comparison of OP-1 probes with other bone morphogenetic proteins, the identity did not exceed $29 \%$ [BMP-2 (27\%), BMP-3 (28\%), BMP-4 (26\%), BMP-5 (24\%), BMP-6 (29\%)], both before and after alkaline hydrolysis, making cross-reactivity unlikely (GeneWorks 2.2.1, IntelliGenetics ${ }^{\mathrm{TM}}$, CA). Single-strained sense and anti-sense RNA probes were labelled with $\left[\alpha^{-35}\right.$ S]UTP (New England Nuclear, Boston, MA) by in vitro-transcription using either SP6 or T7 polymerase.

\section{In situ hybridization}

For in situ hybridization, sections were cut at 5-7 $\mu \mathrm{m}$ thickness, mounted on silanated slides, heated at $45^{\circ} \mathrm{C}$ overnight, and kept at $4{ }^{\circ} \mathrm{C}$. They were then deparaffinized, rehydrated, postfixed for $20 \mathrm{~min}$ in $4 \%$ paraformaldehyde and processed as previously described $(17,19)$. Briefly, pre-treatment included incubation in $0.2 \mathrm{~mol} / \mathrm{l} \mathrm{HCl}(5 \mathrm{~min})$, proteinase $\mathrm{K}$-digestion $(20 \mathrm{~g} / \mathrm{l} ; 10 \mathrm{~min}$ ), additional postfixation ( $5 \mathrm{~min}$ ), blocking of non-specific sulphurbinding sites with iodoacetamide $(0.37 \mathrm{~g} / 400 \mathrm{ml} ; 925 \mathrm{mg} / \mathrm{l})$ and N-ethylmaleimide $(0.25 \mathrm{~g} / 400 \mathrm{ml} ; 625 \mathrm{mg} / \mathrm{l})$, acetic anhydride treatment $(5 \mathrm{~g} / \mathrm{l}$ in $0.1 \mathrm{~mol} / \mathrm{l}$ triethanolamine- $\mathrm{HCl}, \mathrm{pH} 8.0 ; 2 \times 10$ $\mathrm{min}$ ), and dehydration using a graded series of ethanol. Sections were hybridized under siliconized coverslips for $16-18 \mathrm{~h}$ at $50{ }^{\circ} \mathrm{C}$ in a humid chamber in hybridization buffer $(50 \%$ formamide, $10 \%$ dextran sulphate, saline/sodium citrate $(0.60 \mathrm{~mol} / \mathrm{l}$ $\mathrm{NaCl}, 0.060 \mathrm{~mol} / 1 \mathrm{Na}$-citrate, $\mathrm{pH} \mathrm{7}), 10 \mathrm{mmol} / \mathrm{l}$ dithiothreitol, Denhardts solution $(200 \mathrm{mg} / \mathrm{l}$ bovine serum albumin, $200 \mathrm{mg} / \mathrm{l}$ Ficoll, $200 \mathrm{mg} / \mathrm{l}$ polyvinylpyrrolidone); $500 \mathrm{mg} / \mathrm{l}$ each of salmon sperm DNA and yeast tRNA, and $0.2-0.4 \mathrm{mg} / 1{ }^{35} \mathrm{~S}$-labelled asymmetric RNA probes. After hybridization the sections were washed essentially as described earlier (17), including the following steps: $15 \mathrm{~min}$ in saline/sodium citrate $(0.30 \mathrm{~mol} / \mathrm{l}$ $\mathrm{NaCl}, 0.030 \mathrm{~mol} / 1 \mathrm{Na}$-citrate), $50^{\circ} \mathrm{C} ; 20 \mathrm{~min}$ in $50 \%$ formamide Na-citrate $(0.30 \mathrm{~mol} / \mathrm{l} \mathrm{NaCl}, 0.030 \mathrm{~mol} / \mathrm{l} \mathrm{Na}$-citrate, $20 \mathrm{mmol} / \mathrm{l}$ dithiothreitol), $65^{\circ} \mathrm{C} ; 2 \times 10 \mathrm{~min}$ in Tris/EDTA/NaCl buffer (10 $\mathrm{mmol} / \mathrm{l}$ Tris- $\mathrm{HCl}, \mathrm{pH} 7.5 ; 5 \mathrm{mmol} / 1$ EDTA, $0.5 \mathrm{~mol} / 1 \mathrm{NaCl})$, $37^{\circ} \mathrm{C} ; 30 \mathrm{~min}$ in Tris/EDTA $/ \mathrm{NaCl}$ buffer containing $20 \mathrm{mg} / \mathrm{l}$ RNase A, $37^{\circ} \mathrm{C} ; 10 \mathrm{~min}$ in Tris/EDTA/NaCl buffer, $37^{\circ} \mathrm{C}$; $2 \times 15 \mathrm{~min}$ in saline/sodium citrate $(0.30 \mathrm{~mol} / 1 \mathrm{NaCl}, 0.030$ $\mathrm{mol} / \mathrm{l} \mathrm{Na}$-citrate), $65^{\circ} \mathrm{C}$; and finally to $15 \mathrm{~min}$ washes in saline/ sodium $\left(0.15 \mathrm{~mol} / \mathrm{l} \mathrm{NaCl}, 0.015 \mathrm{~mol} / \mathrm{l} \mathrm{Na}\right.$-citrate), $65^{\circ} \mathrm{C}$. Sections were then dehydrated through an upgraded series of ethanol containing $0.3 \mathrm{~mol} / \mathrm{l}$ ammonium acetate, covered with NTB-2 emulsion (Kodak), and exposed between 1 and 3 weeks. After development, the slides were stained with $1 \mathrm{~g} / 1$ toluidine blue, dehydrated, cleaned with xylene and mounted with Permount.

\section{OP-1 antibodies production}

Several polyclonal and monoclonal antibódies that recognize specifically the mature osteogenic protein-1 molecule have been produced and characterized (19). Briefly, the polyclonal rLOP antibody was generated in rabbits using the mature domain of osteogenic protein-1 subunit (amino acids 293-431) (2) expressed in Escherichia coli as immunogen. The polyclonal SER-17 antibody was generated in rabbits using a synthetic peptide of 17 amino acids representing the $\mathrm{N}$-terminus of mature osteogenic protein-1 monomer (amino acids 293-309) (2). Two monoclonal antibodies, $I B 12-D 3$ and $12 G 3$, capable of neutralizing osteogenic protein-1 activity were also used for immunohistochemical staining.

\section{Preparation of dispersed mononuclear trophoblasts}

Normal placentas (8-12 weeks gestation) were obtained immediately after therapeutic procedures and processed according to the modified method of Klinian et al. (29). The tissue was rinsed in sodium chloride $(9 \mathrm{~g} / \mathrm{l})$ containing bacitracin (Serva, Heidelberg, Germany; $4 \mathrm{mg} / \mathrm{l}$ ) and leupeptin (Boehringer, Mannheim, Germany; $3 \mathrm{mg} / \mathrm{l}$ ). The specimens were then dissected free of connective tissue and blood vessels, coarsely minced and transferred to $20 \mathrm{ml}$ pre-warmed calcium-magnesium free Hanks' solution (CMF Hanks'; Sigma Diagnostics, St. Louis, USA), containing $25 \mathrm{mmol} / \mathrm{h}$ HEPES (Sigma), $0.75 \mathrm{~g} / \mathrm{l}$ trypsin (Sigma; $1070 \mathrm{U} / \mathrm{mg}$ ) and $0.6 \mathrm{~g} / 1$ DNase I (Sigma; 530 Kunitz units/mg), pH 7.4, and finally incubated in a shaking water bath at $37^{\circ} \mathrm{C}$ for $20 \mathrm{~min}$. Tissue fragments were allowed to settle for $1 \mathrm{~min}$. Supernatant $(15 \mathrm{ml})$ was removed, recovered in medium containing fetal calf serum (Gibco, Gaithersburg, USA) and centrifuged at $300 \mathrm{~g}$ for $5 \mathrm{~min}$ at room temperature. The resultant pellet was resuspended in $5 \mathrm{ml} \alpha$-MEM (Sigma) containing $25 \mathrm{mmol} / \mathrm{l}$ HEPES, fetal calf serum, volume fraction 0.1 , and $25 \mathrm{mmol} / 1$ glucose and stored at $4^{\circ} \mathrm{C}$. The remaining placental tissue was digested four more times with the addition of $20 \mathrm{ml}$ pre-warmed trypsin-DNase solution. Five resultant cell suspensions were pooled, centrifuged at $300 \mathrm{~g}$ for $5 \mathrm{~min}$, and resuspended in $3 \mathrm{ml} \alpha$-MEM-HEPES-glucose.

\section{Culture of trophoblasts}

The suspension of isolated cells was layered over a preformed Percoll gradient made up in Hanks' solution. The gradient consisted of $70 \%$ to $20 \%$ Percoll (vol/vol) in $10 \%$ steps of $3 \mathrm{ml}$ each, by dilutions of $90 \%$ Percoll [ 9 parts Percoll (Pharmacia, Uppsala, Sweden): 1 part 10 times concentrated Hanks'] with calcium-magnesium free Hanks' and layered in a $25 \mathrm{ml}$ conical polystyrene centrifuge tube. The gradient was then centrifuged at $400 \mathrm{~g}$ at room temperature for $20 \mathrm{~min}$ and three regions were identified, namely:

(1) red blood cells and occasional polymorphonuclear leukocytes at the bottom,

(2) connective tisssue elements, small vessels and villous fragments at the top, and

(3) mononuclear cells in the middle.

The middle layer was removed, washed once with $\alpha$-MEMHEPES-glucose, resuspended and diluted to a concentration of $3 \times 10^{8}$ cells per litre with $\alpha$-MEM containing glutamine (Flow, Bucks, England; $292.3 \mathrm{~g} / \mathrm{l}$ ), penicillin and streptomycin (Sigma; $100000 \mathrm{U} / \mathrm{l}, 0.1 \mathrm{~g} / \mathrm{l})$, and fetal calf serum, volume fraction 0.15 . The cells were plated into 96-well plates (Flow; $200 \mathrm{ml}, 60000$ cells/well) incubated in a humidified atmosphere with $5 \% \mathrm{CO}_{2}-$ $95 \%$ air at $37^{\circ} \mathrm{C}$ for 24 hours. The culture medium was then supplemented with $1 \mathrm{~g} / 1$ bovine serum albumin and $1 \%$ ITS + TM premix [Collaborative Research Inc., Bedford, USA; containing insulin $(6.25 \mathrm{~g} / \mathrm{l})$, transferrin $(6.25 \mathrm{~g} / \mathrm{l})$, selenious acid $(6.25 \mathrm{~g} / \mathrm{l})$, bovine serum albumin $(1.25 \mathrm{~g} / \mathrm{l})$, linoleic acid $(5.35 \mathrm{~g} / \mathrm{l})]$, osteogenic 

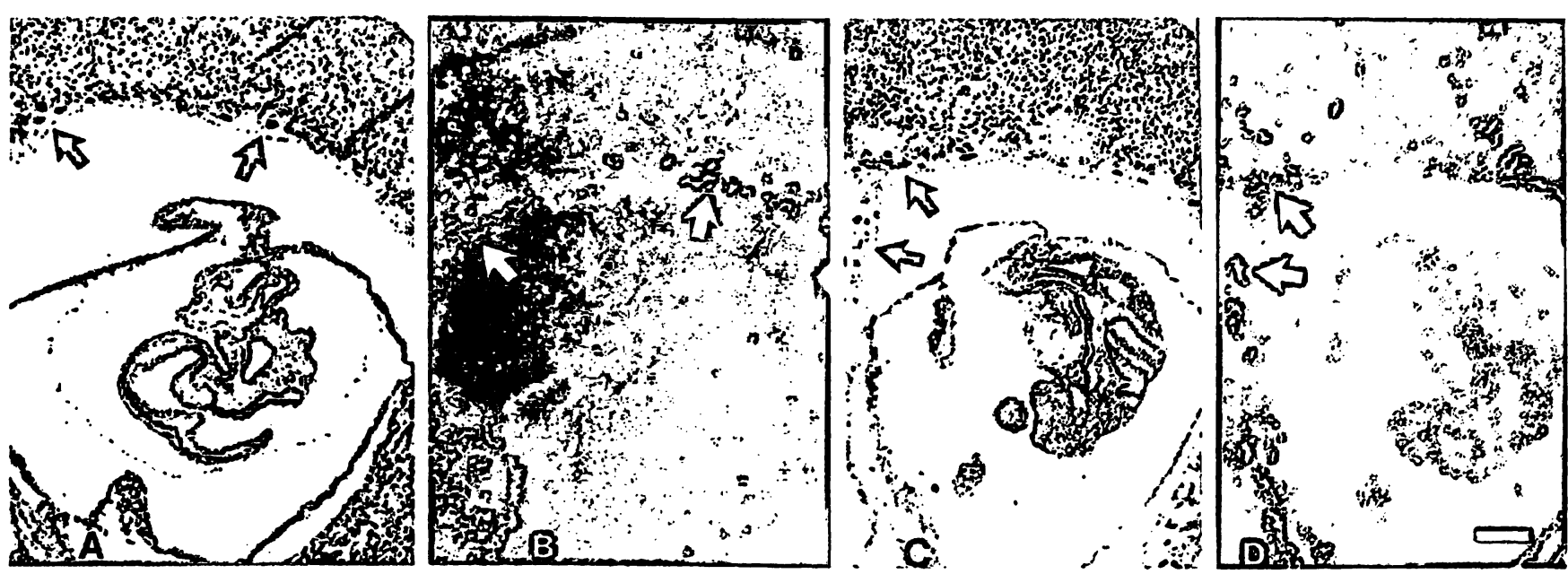

Fig. 1 OP-1 expression in the murine pregnant uterus by in situ hybridization. Hybridization was done with a 679 base pair BstXI-Bgll OP-I specific riboprobe.

(A) Transverse toluidine-blue stained brightfield section of a 7-day pregnant uterus. Arrows indicate layers of giant cytotrophoblast adjacent to maternal placenta. The developing embryo is in the middle of the section. Magnification: $\times 60$

(B) Darkfield image of an adjacent section with transcripts localized in the cytotrophoblasts of the placenta (arrows). Magnification: $\times 60$

protein-1 [Creative BioMolecules, Hopkinton, MA, USA $(20$ $\mathrm{mg} / \mathrm{l})$ ] and bone morphogenetic protein-2 [Creative BioMolecules, Hopkinton, MA, USA, (20 mg/l)]. At designed times, culture media were removed, frozen at $-70^{\circ} \mathrm{C}$ and replaced with fresh medium. Cells were cultured for up to 5 days. Experiments following each isolation of trophoblasts were done in triplicate, with 12 wells per group.

\section{Immunostaining methods}

Sections were deparaffinized and then treated with $1000 \mathrm{U} / 1$ chondroitinase ABC (Sigma Diagnostics, St. Louis, USA) for 10 min at $37^{\circ} \mathrm{C}$ to facilitate the antibody penetration into the tissues. This was followed by exposing the sections to $1: 30$ dilution of normal goat serum (Amersham, Buckinghamshire, England) for $30 \mathrm{~min}$. Sections were then incubated with a dilution of the primary antibody in TRIS-buffered saline $(15 \mathrm{mg} / \mathrm{l}$ protein), $5 \mathrm{~g} / \mathrm{l}$ bovine serum albumin (Sigma), overnight at $4^{\circ} \mathrm{C}$ After washing in TRIS-buffered saline containing $1 \mathrm{~g} / \mathrm{l}$ bovine serum albumin, sections were incubated for one hour with an affinity-purified secondary antibody, linked to colloidal gold particles of about $5 \mathrm{~nm}$ mean diameter (Auroprobe LM; Janssen, Olsen, Belgium). For control experiments, the primary antibody was replaced with either

(a) bovine serum albumin,

(b) normal rabbit serum,

(c) IgG preabsorbed with osteogenic protein-1,

(d) secondary antibody alone or

(e) by using the antigen-depleted IgG preparations.

\section{Hormone quantification}

For the determination of hormone production by cultured trophoblasts conditioned media were collected and stored at $-70^{\circ} \mathrm{C}$ until analysed. Oestradiol was determined by a radioimmunoassay, progesterone was measured using an enzyme immunoassay, and the $\beta$-subunit of human chorionic gonadotropin by immunoenzymetric assay with magnetic solid phase (Serono diagnostics, Coinsins, Switzerland).

\section{Statistics}

All results are expressed as mean \pm SEM. Data (12 wells per experimental group) were tested by Student's t-test, followed by two-
(C) Toluidine-blue stained section of uterus containing the fetus of a 10-day pregnant mouse. Arrows indicate trophoblastic giant cells. Magnification: $\times 60$

(D) An adjacent darkfield section with a strong signal in the trophoblastic giant cells (arrows). Bar in (d) indicates $100 \mu \mathrm{m}$ in $(a-d)$. Magnification: $\times 60$

way analysis of variance (ANOVA). Means were then tested by the Scheffe-post-hoc test. Siudent's t-test, ANOVA and Scheffepost-hoc tests were performed with the "Crunch" statistical package.

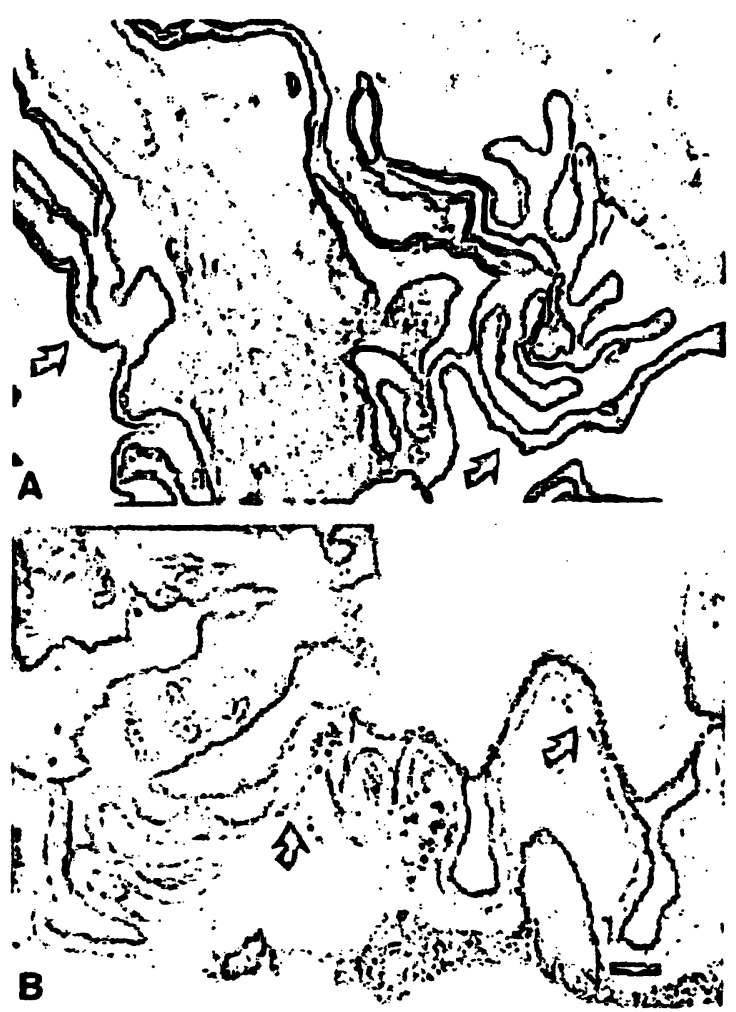

Fig. 2 Specificity of osteogenic protein-1 staining.

(A) Parasagittal section through the placenta of a $22 \mathrm{~mm}$ embryo The $r L O P$ antibody to osteogenic protein-1 causes intense staining of the chorionic cell layer (arrows). Magnification: $\times 25$

(B) An equivalent aliquot of antibody preincubated with a solution to which osteogenic protein-1 had been added gave no staining (arrows). The dilution of the anti-osteogenic protein-1 IgG preparation was $1: 150$. Immunogold staining with light green counterstain. Bar indicates $20 \mu \mathrm{m}$. Magnification: $\times 25$ 


\section{Results}

Osteogenic protein-1 expression in murine trophoblasts

At 7 to 10 days of murine pregnancy, the OP-1 mRNA expression was observed mainly in trophoblastic giant cells of the fetal placenta (fig. 1a-d) and remained in cytotrophoblasts during subsequent development (data not shown). There were no detectable OP-1 transcripts in endometrium constituting the maternal placenta. Localization of OP-1 in fetal tissues is in accordance with our previous observations $(17,19)$.

\section{Localization of osteogenic protein-1 in human placenta during pregnancy}

Specificity of immunostaining was initially tested by using the polyclonal $r L O P$ antibody raised against mature OP-1 monomer and then by employing the polyclonal SER-17 (raised against N-terminal peptide of mature OP-1) and monoclonal $1 B 12-D 3$ antibodies (raised against mature OP-1 dimer) (18). The specificity of immunostaining to osteogenic protein-1, was demonstrated by preincubating the anti-osteogenic protein-1 IgG fractions with a solution of $5 \mathrm{mg} / \mathrm{l}$ of recombinant human osteogenic protein-1 before use. This procedure resulted in a complete loss of staining, thus demonstrating that the osteogenic protein-1 immunoreactivity is specific (fig. 2a, b). Since the placenta continuously undergoes changes in size, shape and internal structure during gestation, osteogenic protein-1 distribution was examined in placentas from 2, 3, 6, 13, 27 and $33 \mathrm{~mm}$ embryos, as well as in full term placentas. Intensive cytoplasmic staining was observed in the chorionic cell layers by the polyclonal $r L O P$ antibody (fig. $3 \mathrm{a}$, b). Osteogenic protein-1 was detected in the cytotrophoblast layer (Langhans' layer) (fig. 3d) of chorionic villi, which reach the peak of their development during the second month and regress from the 13th week onwards. Hofbauer cells (fig. 3d), which appear to be phagocytic and are commonly believed to act as a primitive type of macrophage, also stained for osteogenic protein-1. In full term placentas, the remaining cytotrophoblasts still stained for osteogenic protein-1. These findings suggest a role for osteogenic protein-1 in early enbryogenesis and remodelling of the placenta.

\section{Osteogenic protein-1 inhibits hormonal secretion of cultured human trophoblasts}

Highly purified functional cytotrophoblasts were prepared from early and full-term human placentas. The lack of immunogold staining with antibodies against vimentin, von Willebrand-factor VIII and $\alpha_{1}$-antichymotrypsin confirmed Kliman's data (29) that endothelial cells, fibroblasts, or macrophages did not contaminate the purified cytotrophoblast preparations. Figure 4 shows isolated human cytotrophoblasts in culture and formation of human chorionic gonadotropin-positive syncytia over a period of $18-66$ hours. Hormonal secretion was detected 24 hours after culturing the cells, which correlated with the beginning of cell aggregation. Isolated human trophoblasts showed a steadily increasing synthesis of human chorionic gonadotropin and pro-
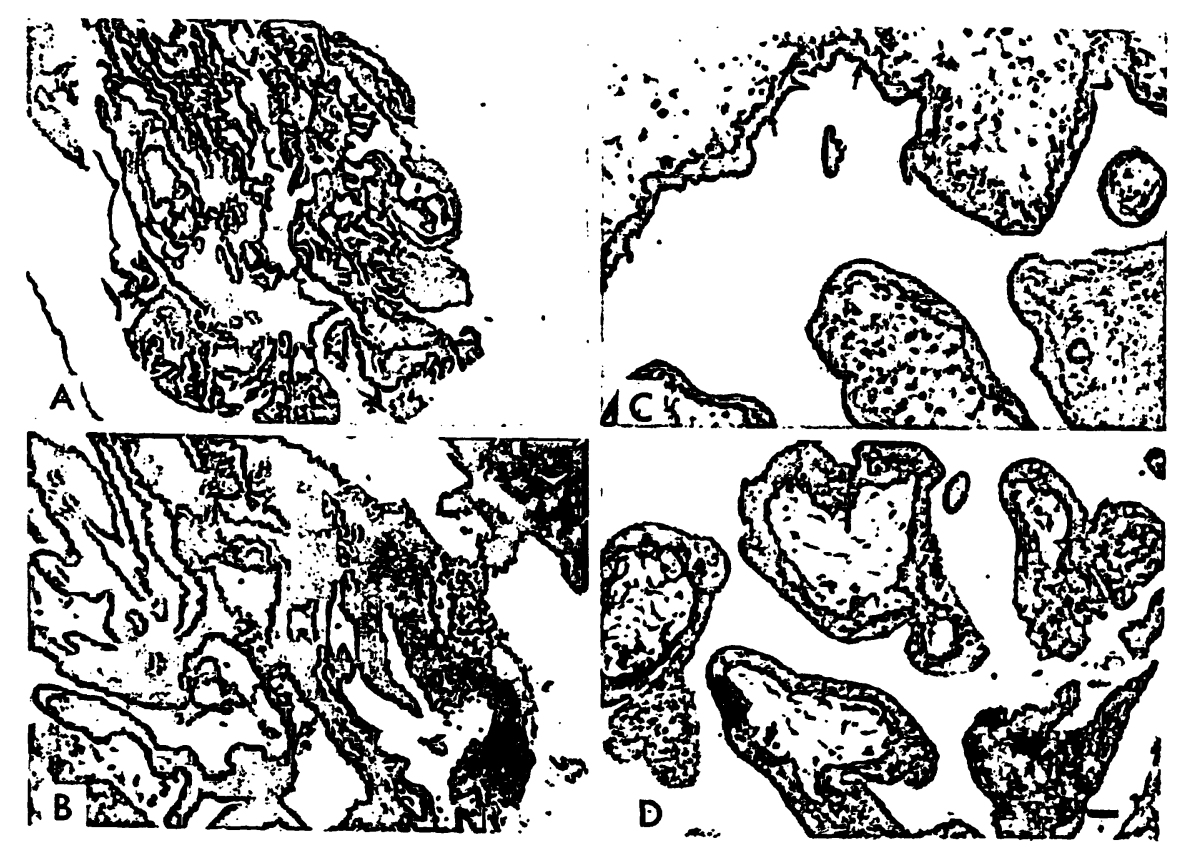

Fig. 3 Localization of osteogenic protein-1 in early human placenta. (A) A chorionic cell layer of a $27 \mathrm{~mm}$ embryo stains intensely for osteogenic protein-1 with $r$ LOP antibody. Magnification: $\times 5$

(B) Higher magnification of (a). Magnification: $\times 25$

(C) Chorionic villi from the placenta of a $13 \mathrm{~mm}$ embryo. Osteogenic protein-1 is detectable in the cytotrophoblast cell layer (arrows.). Magnification: $\times 25$

(D) Staining of full term placental tissues with a monoclonal IB12$D 3$ antibody. Remaining cytotrophoblasts continue to show the presence of osteogenic protein-1 (arrows). Immunogold staining with light green counterstain. Magnification: $\times 25$.

Bar indicates $100 \mu \mathrm{m}$ in (A), $20 \mu \mathrm{m}$ in (B, C, D). 
gesterone, reaching maximal values by 96 hours in the presence of fetal calf serum, volume fraction 0.15 (fig. $5 a, b)$. To test the possible effect of osteogenic protein1 on hormonal activity of isolated trophoblast cells, different amounts $(1-100 \mathrm{mg} / \mathrm{l})$ of osteogenic protein-1 were added to cultured cells 24 hours after plating. Both
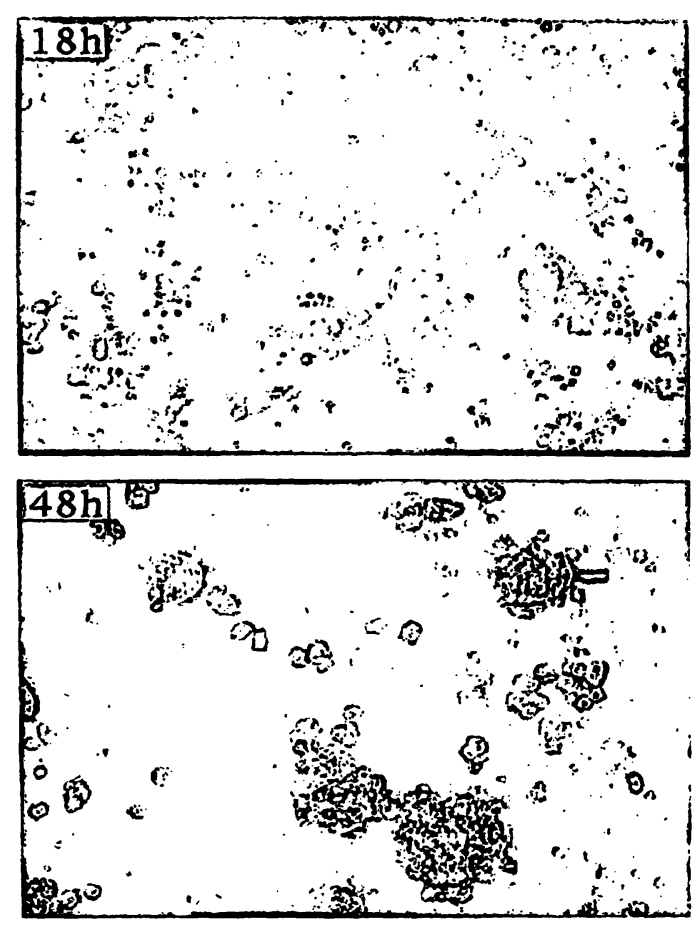

Fig. 4 Human trophoblasts in culture.

Highly purified functional cytotrophoblasts were isolated from early human placentas and grown in $\alpha-M E M$ containing glutamine and $150 \mathrm{ml} / \mathrm{l}$ fetal calf serum for up to 5 days as described in Material and Methods. Cells were seeded at $300 \times 10^{6} / 1$ in 96 -well

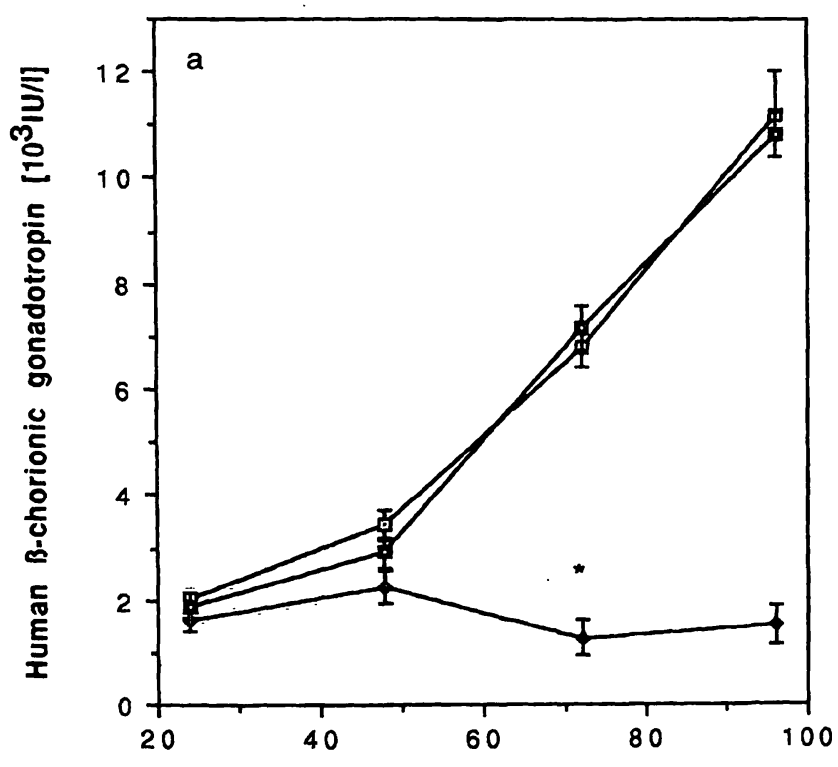

Fig. 5 Hormonal secretion by human trophoblasts treated with a single dose of osteogenic protein-1. Cells were cultured in $\alpha$-MEM containing glutamine and $5 \mathrm{ml} / 1$ fetal calf serum for up to five days in 96-well plate $(60000 /$ well), with the addition of osteogenic protein-1 or bone morphogenetic protein- 2 as indicated. Addition of a single dose of $20 \mathrm{mg} / \mathrm{l}$ osteogenic protein-1 24 hours after plating the cells reduced the secretion of chorionic gonadotropin (fig. 5a) and progesterone (fig. $5 b)$ secretion into the conditioned media were decreased by $60 \%$ and $36 \%$ at 72 hours, respectively. The inhibition was maximal in the presence of $20 \mathrm{mg} / \mathrm{l}$ osteogenic protein- 1 and most effective in the presence of $5 \mathrm{ml} / \mathrm{l}$ of fetal calf serum. At a high serum content $(150 \mathrm{ml} / \mathrm{l})$ in
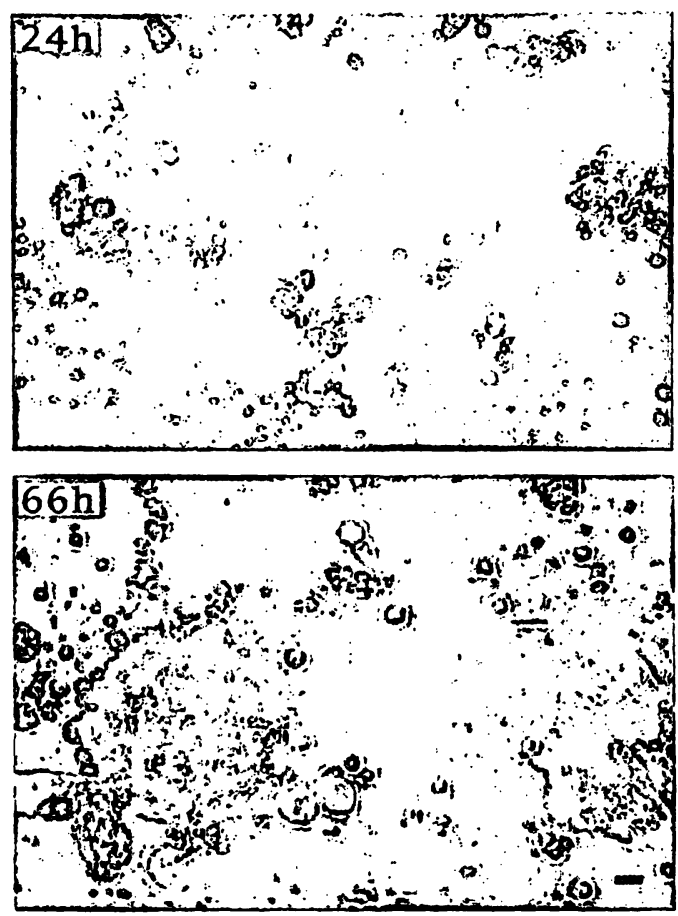

plates (60000/well). Cell aggregates formed as early as 24 hours after plating; these eventually fused to form functional syncytiotrophoblasts 24-48 hours after plating. Bar indicates $500 \mu \mathrm{m}$ in $(18 \mathrm{~h}), 380 \mu \mathrm{m}$ in $(24 \mathrm{~h}), 250 \mu \mathrm{m}$ in $(48 \mathrm{~h})$ and $100 \mu \mathrm{m}$ in $(66 \mathrm{~h})$. Magnification: $\times 12(18 \mathrm{~h}), \times 32(24 \mathrm{~h}, 48 \mathrm{~h}), \times 50(66 \mathrm{~h})$

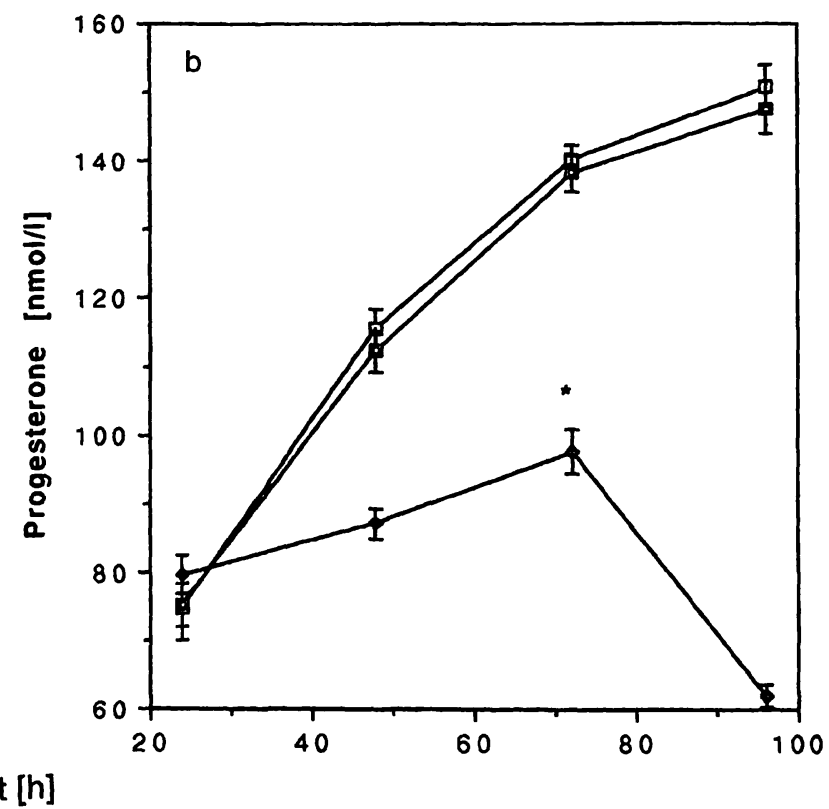

(a) chorionic gonadolropin in trophoblast conditioned media by $60 \%$,

(b) progesterone secretion by $36 \%$.

Bone morphogenetic protein-2 (recombinant human BMP-2, 20 $\mathrm{mg} / \mathrm{l}$ ) had no effect on hormone secretion. Experiments were done in triplicate, with 12 ivells per group $(n=12)$.

$* \mathrm{P}<0.01$ vs control.

$-\square-$ control $\rightarrow-$ rhOP-1 - - rhBMP-2 
the presence of various amounts of osteogenic protein1 , the differences were less pronounced (data not shown). The most effective reduction in the secretion of chorionic gonadotropin at low fetal calf serum concentration was achieved by the addition of $20 \mathrm{mg} / \mathrm{l}$ of osteogenic protein-1 immediately after plating (fig. 6). Low chorionic gonadotropin values were maintained throughout the experiment by the daily addition of osteogenic protein-1.

\section{Discussion}

The present study identifies cytotrophoblasts in the human fetal placenta as a site of OP-1 synthesis during pregnancy. Moreover, OP-1 seems to be involved in the regulation of secretion of chorionic gonadotropin and

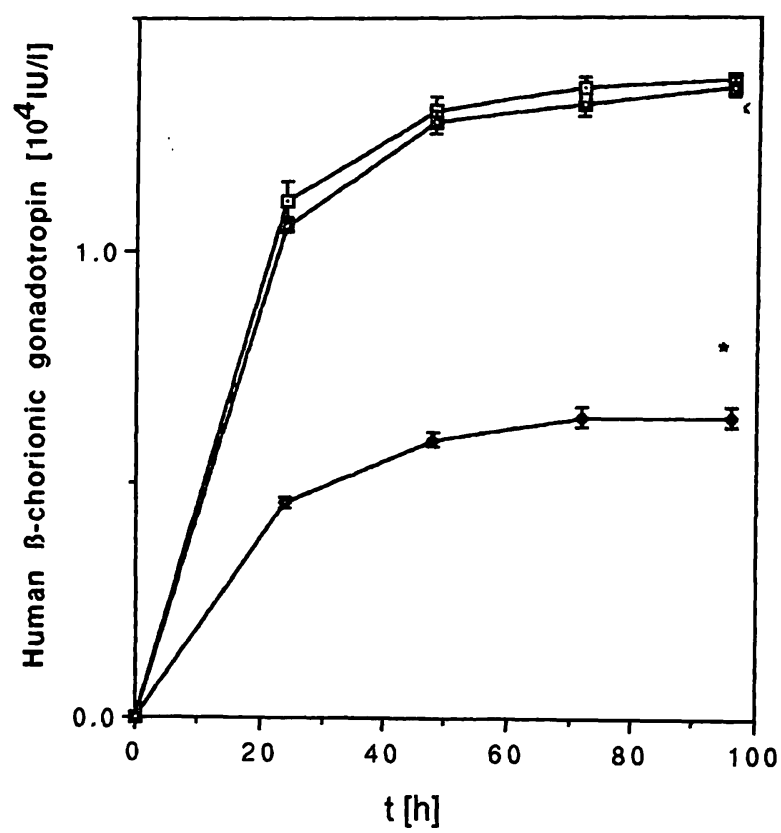

Fig. 6 Hormonal secretion by human trophoblasts treated daily with osteogenic protein-1. Cells were cultured in $\alpha$-MEM containing glutamine and $5 \mathrm{ml} / \mathrm{l}$ fetal calf serum for up to five days in a 96-well plate $(60000 /$ well), with the addition of osteogenic protein-1 or bone morphogenetic protein-2 as indicated. Administration of osteogenic protein-1 $(20 \mathrm{mg} / \mathrm{l})$ immediately after plating, caused a pronounced decrease in chorionic gonadotropin secretion by human trophoblasts within 24 hours. In parallel, bone morphogenetic protein-2 (recombinant human BMP-2, $20 \mathrm{mg} / \mathrm{l}$ ) had no effect on hormone secretion. Experiments following each isolation of trophoblasts were done in triplicate, with 12 wells per group $(n=12)$.

$* \mathrm{P}<0.01$ vs control.

$-\square-$ control $\rightarrow-$ rhOP-1 $-\square-$ rhBMP-2

\section{References}

1. Ling N, Ying SY, Ueno N, Shimasaki S, Esch F, Hotta M, et al. Pituitary FSH is released by a heterodimer of the b-subunits from the two forms of inhibin. Nature 1986; 321:779-82.

2. Özkaynak E, Rueger DC, Drier EA, Corbett C, Ridge RJ, Sampath TK, et al. OP-1 cDNA encodes an osteogenic protein in the TGF $\beta$ superfamily. EMBO J 1990; 9:2085-93.

3. Özkaynak E. Schnegelsberg PNJ, Jin DF, Clifford GM, Warren FD, Drier EA, et al. Osteogenic protein-2. J Biol Chem $1992 ; 267: 25220-7$ progesterone by cytotrophoblasts. During pregnancy both placental cytotrophoblasts and the developing embryo synthesize OP-1. Expression of OP-1 appears to correlate with the biochemical changes associated with trophoblasts, as evidenced by the secretion of increased amounts of chorionic gonadotropin and its peak values during the first trimester of pregnancy. The specific activity of OP-1 on placental hormone secretion was further corroborated by the failure of morphogenetic protein-2 to inhibit.the same assay system. Analysis of the spatial and temporal expression of OP-1 patterns during development showed a widespread distribution of OP-1 expression at the sites of specific developmental events involving epithelial mesenchymal interaction (20). The detection of OP-1 message in tissues like the kidney, heart, early limb buds, whisker follicles and teeth, indicates that OP-1 may have, apart from bone induction, important signalling or regulatory roles during epithelial-mesenchymal interactions. This has been previously suggested for other members of the TGF- $\beta$ superfamily (17). Although both OP-1 and BMP-2 induce new bone and cartilage formation at ectopic sites and share type I and II, two cell surface receptors, their specific functional roles during development are yet to be discovered. This system provides a good basis for delineating the apparent functional differences among the bone morphogenetic protein family members.

Since pregnancy and/or the administration of oestrogen regulates the expression of osteogenic protein-1 in the uterus, cytotrophoblasts and fetal organs, it is possible that the osteogenic protein-1 gene may have tissue-specific regulatory elements in the upstream 5 ' characterization of promotor region. Upstream regulatory sequences in the osteogenic protein-1 genomic locus, with specific binding sequences for transcriptional regulatory protein would provide a better understanding of the temporal and spatial regulation of OP-1 during tissue morphogenesis. Recent studies on deletion of the OP-1 gene suggest that mice carrying the null mutation died due to lack of a functional kidney, as well as displaying several skeletal abnormalities and dysfunction of the fetal placenta, resulting in a small, underdeveloped animal (Karsenty et al., in preparation). These observations further support our conclusion that OP-1 has a regulatory role in the placental cytotrophoblasts during pregnancy.

4. Wozney JM, Rosen V, Celeste AJ, Mitsock LM, Whitters MJ, Kriz RW, et al. Novel regulators of bone formation: molecular clones and activities. Science 1988; 242:1528-34.

5. Celeste AJ, Ianazzi JA, Taylor RC, Hewick RM, Rosen V, Wang EA, et al. Identification of transforming growth factor $\beta$ family members present in bone-inductive protein purified from bovine bone. Proc Natl, Acad Sci USA 1990; $87: 9843-7$ 
6. Rebagliatti MR, Weeks DL, Harvey RP, Melton DA. Identification and cloning of localized maternal RNAs from Xenopus eggs. Cell 1985; 42:769-77.

7. Cate RL, Mattaliano RJ, Hession C, Tizard R, Farber NM, Cheung $A$, et al. Isolation of the bovine and human genes for Muellerian inhibiting substance and expression of the human gene in animal cells. Cell 1986; 45:685-98.

8. Lyons K, Graycar JL, Lee A, Hashmi S, Lindquist PB, Chen $\mathrm{EY}$, et al. Vgr-1, a mammalian gene related to Xenopus Vg-1, is a member of transforming growth factor $\beta$ gene superfamily. Proc Natl Acad Sci USA 1989; 86:4554-8.

9. Lee SJ. Expression of growth/differentiation factor 1 in the nervous system: conservation of a bicistronic structure. Proc Natl Acad Sci USA 1991; 88:4250-4.

10. McPherron AC, Lee SJ. The two members of the transforming growth factor superfamily containing novel pattern of cysteines. J Biol Chem 1993; 268:3444-9.

11. Chang SC, Hoang B, Thomas TJ, Vukičević S, Luyten FP, Ryba NJP, et al. Cartilage derived morphogenetic proteins. New members of the TGF- $\beta$ superfamily predominantly expressed in long bones during human embryonic development. J Biol Chem 1994; 269:28227-34.

12. Storm EE, Huynh TV, Copeland NG, Jenkins NA, Kingsley DM, Lee SJ. Limb alterations in brachypodism mice due to mutations in a new member of the TGF $\beta$-superfamily. Nature 1994; 368:639-43.

13. Padgett RW, Johnson ST, Gelbart WM. A transcript from a Drosophila pattern gene predicts a protein homologous to the transforming growth factor $\beta$ family. Nature $1987 ; 325: 81-4$.

14. Wharton KA, Thomsen GH, Gelbart WM. Drosophila 60A gene, a new transforming growth factor $\beta$ family member is closely related to human bone morphogenetic proteins. Proc Natl Acad Sci USA 1991; 88:9214-8.

15. Massague J. The transforming growth factor $\beta$ family. Annu Rev Cell Biol 1990; 6:597-641.

16. Vukičević S, Paralkar VM, Reddi AH. Extracellular matrix and bone morphogenetic proteins in cartilage and bone development and repair. Adv Mol Cell Biol 1993; 6:207.

17. Vukičević S, Helder MN, Luyten FP. The developing human lung is a major site of synthesis of bone morphogenetic protein-3 (osteogenin). J Histochem Cytochem 1994; 42:869-75.

18. Vukičević S, Latin V, Chen P, Batorsky R, Reddi AH, Sampath TK. Localization of osteogenic protein-1 (bone morphogenetic protein-7) during human embryonic development: high affinity binding to basement membranes. Biochem Biophys Res Commun 1994; 198:693-700.

19. Helder MN, Özkaynak E, Sampath KT, Luyten FP, Latin V, Oppermann H, Vukičević S. Expression pattern of osteogenic protein-1 (bone morphogenetic protein-7) in human and mouse development. J Histochem Cytochem 1995; 43:1035-44.

20. Ripamonti U, Vukičević S. Bone morphogenetic proteins: from developmental biology to molecular therapeutics. S African J Sci 1995; 91:277-80.

21. Sampath TK, Maliakal JC, Hauschka PV, Jones WK, Sasaki $\mathrm{H}$, Tucker RF, et al. Recombinant human osteogenic protein-1 (hOP-1) induces new bone formation in vivo with specific activity comparable to natural bovine osteogenic protein and stimulates osteoblast proliferation and differentiation in vitro. J Biol Chem 1992; 267:20352-62.

22. Chen P, Carrington JL, Hammonds RG, Reddi AH. Stimulation of chrondrogenesis in limb bud mesoderm cells by recombinant BMP-2B and modulation by TGF- $\beta 1$ and TGF- $\beta 2$. Exp Cell Res 1992; 195:509-15.

23. Sampath TK, Coughlin JE, Whetstone RM, Banach D, Corbett $C$, Ridge RJ, et al. Bovine osteogenic protein is composed of dimers of OP-1 and BMP-2A, two members of the transforming growth factor- $\beta$ superfamily. J Biol Chem 1990; 265:13198-205.

24. Vukičević S, Luyten FP, Reddi AH. Stimulation of the expression of osteogenic and chondrogenic phenotypes in vitro by osteogenin. Proc Natl Acad Sci USA 1989; 86:8793-7.

25. Vukičević S, Luyten FP, Reddi AH. Osteogenin inhibits proliferation and stimulates differentiation in mouse osteoblast-like cells (MC 3T3-E1). Biochem Biophys Res Commun 1990; 166:750-6.

26. Vukičević S, Paralkar VW, Cunningham NS, Gutkind JS, Reddi AH. Autoradiographic localization of osteogenin binding sites in cartilage and bone during rat embryonic development. Dev Biol 1990; 140:209-14.

27. Özkaynak E, Schnegelsberg PNJ, Opperman H. Murine osteogenic protein-1 (OP-1): high levels of mRNA in kidney. Biochem Biophys Res Commun 1991; 179:116-23.

28. Özkaynak E, Jin DF, Vukičević, Opperman H. mRNA of OP1 morphogenetic protein in the uterus: negative regulation by estrogen, in preparation.

29. Kliman HJ, Nestler JE, Sermasi E, Sanger JM, Strauss F. Purification, characterization and in vitro differentiation of cytotrophoblasts from human term placentae. Endocrinology 1986; 118:1567-82.

\section{Received March 3/November 11, 1995}

Corresponding author: Professor Slobodan Vukičević, M. D. Ph. D., Department of Anatomy, Zagreb University School of Medicine, Šalata 11, HR-10000 Zagreb, Croatia 
